Thémata. Revista de Filosofía.

\title{
Sonette / Sonetos, J. G. Fichte.
}

\author{
Nazahed Franco Bonifaz' \\ Universidad de Guanajuato, México. \\ Recibido 30 marzo 2021 A Aceptado 10 abril 2021
}

1.nazahed@hotmail.com

1 Fichte, Johann Gottlieb; sämmtliche Werke 8; herausgegeben von I. H. Fichte; pp. 461-2. De las tres partes que componen el soneto, la primera y la segunda se presentan por vez primera al castellano. De la tercera parte existe una traducción en la Revista de estud(i)os sobre Fichte, no. 8, 2014, y presentamos una nueva versión. 
1

Wenn dir das inn're Götterwort wird spruchlos, Verblasset auch die äussere Verspürung, Was dich umgiebt, verlieret die Verzierung, Was von dir ausgeht, wird nur schnöd' und ruchlos.

Die Blüthe deines Lebens steht geruchlos, Was andre leitet, das wird dir Verführung; Denn du bist ausserhalb des Alls Berührung, Darum wird dir der äuss're Laut auch spruchlos.

Das innen Todte glänze noch so scheinsam, Doch treibt dich fort zu ungemess'ner Wehmuth, Die unaufhaltsam schon dich griff, die Brandung.

Drum bleib' ich in mir selber still und einsam Und pflege fort mit kindergleicher Demuth Das Unterpfand der einst'gen frohen Landung.

1

Cuando dentro de ti la palabra divina se calla, el sentimiento externo también se palidece, el ornato de lo que te rodea se pierde, se vuelve mezquino y vil lo que de ti emana.

La flor de tu vida permanece sin olor, lo que a otros guía a ti te seducirá;

dado que del contacto con el Todo ajeno estás, te será silenciado también el sonido exterior.

Lo que en el interior parece muerto aún brilla, sin embargo, un incesante oleaje te ataca, $\mathrm{y}$ te arrastra a una profunda nostalgia.

Por eso permanezco en mí mismo callado y solitario y cuido con inocente humildad el pecio de lo que alguna vez fue un alegre desembarco. 
2

Was meinem Auge diese Kraft gegeben, Dass alle Missgestalt ihm ist zerronnen, Dass ihm die Nächte werden heitre Sonnen, Unordnung Ordnung, und Verwesung Leben?

Was durch der Zeit, des Raums verworr'nes Weben Mich sicher leitet hin zum ew'gen Bronnen Des Schönen, Wahren, Guten und der Wonnen, Und drin vernichtend eintaucht all' mein Streben?

Das ist's. Seit in Urania's Aug', die tiefe Sich selber klare, blaue, stille, reine Lichtflamm', ich selber still hineingesehen; Seitdem ruht dieses Aug' mir in der Tiefe Und ist in meinem Seyn, - das ewig Eine, Lebt mir im Leben, sieht in meinem Sehen.

2

¿Qué le ha dado esta fuerza a mi ojo, que toda tergiversación en él se ha desvanecido, que las noches en soles alegres ha convertido, el desorden en orden, y la putrefacción en vida?

¿Qué es lo que me guía con seguridad a través del enmarañado tejido espacio-temporal hacia la fuente eterna de la belleza, la verdad, lo grato y la bondad, y que violentamente todas mis aspiraciones devora?

Así es. Desde que yo mismo vi en calma el ojo de Urania, a la profundidad clara de sí misma, azul, silenciosa, llama de luz pura;

desde entonces aquel ojo en lo más hondo de mí reposa y es en mi Ser - la eternidad Una, vive en mi Vida, ve en mi ver. 
3

Nichts ist denn Gott, und Gott ist nichts denn Leben;

Du weissest, ich mit dir weiss im Verein;

Doch wie vermöchte Wissen dazuseyn,

Wenn es nicht Wissen wär' von Gottes Leben!

Wie gern' ach! Wollt' ich diesem hin mich geben, Allein wo find' ich's? Fliesst es irgend ein In's Wissen, so verwandelt's sich in Schein, Mit ihm vermischt, mit seiner Hüll' umgeben.“

Gar klar die Hülle sich vor dir erhebet, Dein Ich ist sie; es sterbe, was vernichtbar, Und fortan lebt nur Gott in deinem Streben.

Durchschaue, was dies Streben überlebet, So wird die Hülle dir als Hülle sichtbar, Und unverschleiert siehst du göttlich' Leben!

3

Nada es, sólo Dios, y Dios no es más que vida;

lo sabes, lo sé contigo en conciliación; sin embargo, ¿cómo podría existir el Saber? ¡Si no fuera por el Saber de la vida divina!

"¡Oh, con qué alegría me entregaría a ello! Sólo que ¿dónde encontrarlo?

Si fluye en el Saber se cubre de un velo, y en la apariencia acaba entremezclado".

Con toda claridad el velo ante ti se alza, él es tu Yo; perezca lo efímero, y en lo sucesivo que Dios viva en tu afán.

¡Escruta lo que perdura en tu afán, sólo así el velo en cuanto velo será visible, y una vez descubierto verás la vida divina! 